\title{
An Empirical Study of Perceived Organizational Support and Affective Commitment in the Logistics Industry
}

\author{
Nguyen Dinh HOA${ }^{1}$, Pham Thi Hong NGAN², Nguyen Minh QUANG ${ }^{3}$, Vu Ba THANH ${ }^{4}$, Huynh Vo Thuc QUYEN \\ Received: May 15, 2020 Revised: May 31, 2020 Accepted: July 03, 2020
}

\begin{abstract}
The study examines the impact of organizational rewards, procedure justice, and perceived supervisor support on perceived organizational support, and examine the impact of perceived organizational support on affective commitment to the organization in the logistic enterprises as well. Quantitative research is applied to measure relationships by regression analysis with SPSS. The research data was collected by convenient method from 180 employees who work in different departments in the logistics industry. The study results in the model 1 found that organizational rewards, procedure justice, and perceived supervisor support have a positive relationship to the perceived organizational support. The study results in the model 2 also found that perceived organizational support has strong impact on the affective commitment to the organization. The study results contribute to both management theory and management practice. For the management theory aspect, the authors suggest that perceived organizational support should be considered the key antecedent of affective commitment about which researchers should pay more attention as a concept. Based on the research results, the authors also recommend for the management practice that managers should pay attention to the implementation of rewards, procedure justice, and supervisor support to increase the perceived organizational support and affective commitment in the logistic enterprises.
\end{abstract}

Keywords: Organizational Rewards, Procedure Justice, Supervisor Support, Organizational Support

JEL Classification Code: M12, M50, M54

\section{Introduction}

Human resources are one of the organization's most important resources. High-quality human resources can provide a sustainable competitive advantage compared to

${ }^{1}$ First Author and Corresponding Author. Dean, Faculty of Labor Relations and Trade Unions, Ton Duc Thang University, Vietnam [Postal Address: No.19, Nguyen Huu Tho Street, Tan Phong Ward, District 7, Ho Chi Minh City, 756600, Vietnam] Email: nguyendinhhoa@tdtu.edu.vn

${ }^{2}$ Lecturer, Faculty of Labor Relations and Trade Unions, Ton Duc Thang University, Vietnam. Email: nganpham25@gmail.com

${ }^{3}$ Lecturer, Faculty of Labor Relations and Trade Unions, Ton Duc Thang University, Vietnam. Email: nguyenminhquang@tdtu.edu.vn ${ }^{4}$ Lecturer, Faculty of Labor Relations and Trade Unions, Ton Duc

Thang University, Vietnam. Email: vbthanh1205@gmail.com

${ }^{5}$ Lecturer, Faculty of Labor Relations and Trade Unions, Ton Duc

Thang University, Vietnam. Email: huynhvothucquyen@tdtu.edu.vn

(c) Copyright: The Author(s)

This is an Open Access article distributed under the terms of the Creative Commons Attribution Non-Commercial License (http://Creativecommons.org/licenses/by-nc/4.0/) which permits unrestricted noncommercial use, distribution, and reproduction in any medium, provided the original work is properly cited. competitors, which is the desire of every enterprise (Singh, Garg, \& Deshmukh, 2010). Therefore, making employees become increasingly committed to the organization is a factor that enterprises need to care about because affective commitment will lead to many other positive behaviors such as an increase in work performance and reduction of turnover (Nguyen \& Ngo, 2020). In the context that the economy has been integrating more and more deeply into the world, the logistics industry is an important service economy, has many advantages and opportunities for development with great potential to contribute to the Vietnamese economy. The industry also makes an important contribution to the distribution of goods from the manufacturing place to consumers and is a bridge for global trade.

To have that contribution, besides the natural advantage, it is necessary to have high-quality human resources. However, there is still a shortage of competent employees in the logistics industry to secure its development. According to the association of the industry nationwide, there are about 1,200 enterprises supplying logistics services, mostly in forwarding, warehousing, and transport agency services 
mainly concentrated in Ho Chi Minh City, with a total number of employees of about 1.5 million, of which Ho Chi Minh City accounts for about $40 \%$. The shortage of competent employees as well as managers in the logistic enterprises highly increases the awareness of the importance of human resource management, so that the employees who are competent in the logistics industry are always interested and treated well by the enterprise.

Therefore, the important thing is how employees voluntarily commit to their organization. When employees love the organization and desire to stick with it as a second family, they will strive to devote and do their best to accomplish the organization's goals. Through the initial observation of the authors, the affective commitment of employees is not only affected by salaries and bonuses, working conditions, promotion opportunities, but also by the perceived organizational support, and that support is influenced by organizational rewards, procedure justice, and perceived supervisor support. These relationships have been demonstrated by previous studies (Rhoades, Eisenberger, $\&$ Armeli, 2001). However, there are currently no studies examining these relationships in Vietnam's logistics industry. Therefore, the authors choose to conduct this study with the goal of measuring the impact of rewards, procedure justice, and perceived supervisor support on perceived organizational support, at the same time examining the impact of perceived organizational support on affective commitment in the logistics enterprises. On that basis, the authors will propose implications to improve the factors to increase perceived organizational support and increase affective commitment in forwarding enterprises in Ho Chi Minh City.

\section{Literature Review}

\subsection{Concepts and Definition}

\subsubsection{Affective Commitment}

Allen and Meyer (1990) defined organizational commitment as the attitude that employee wants to have to attach themselves to the organization. Mathieu and Zajac (1990) said that commitment to an organization is a bond or link between an employee and his organization. Organizational commitment is related to employee believing in the organization's goal and value, and employee effort to attain the organization's goals (Doan, Nguyen, \& Nguyen, 2020). Meyer and Allen (1991) classified three types of commitments: affective commitment, continuance commitment, and moral commitment. According to O'Reilly and Chatman (1986), affective commitment is an affection of attachment, unity, and effort to attain the enterprise goals. Employees committed with strong affection would be devoted to work for the enterprise, simply because they are willing to do so (Meyer \& Allen, 1991). Nguyen and Tu (2020) proved that affective commitment closely impact the job performance.

\subsubsection{Perceived Organizational Support}

Eisenberger, Huntington, Huchison, and Sowa (1986) defined perceived organizational support as the perception of employees, when their contributions to the organization were highly recognized and they received welfare policy from the organization. According to George, Reed, Ballard, Colin, and Fielding (1993), perceived organizational support was seen as an assurance that employees would always receive the necessary support and help from the organization to perform their works and to solve problems effectively. According to Jain and Sinha (2005), perceived organizational support meant the social affection needs, efforts, commitment, and loyalty of an individual recognized by that organization.

\subsubsection{Perceived Supervisor Support}

Employees expect to be supported by a supervisor in their work by taking care of them and recognizing their contributions to the group's working performance (Eisenberger, Stinglhamber, Vandenberghe, Sucharski, \& Rhoades, 2002). Employees developed a shared viewpoint of the level that the supervisors evaluated their work performance and took care of their enjoyment (Kottke \& Sharafinski, 1988). Because the supervisors on behalf of the organization to direct and evaluate the results of their subordinates. Employees were always aware of the supervisor's support through caring and helping them (Eisenberger, Huntington, Huchison, \& Sowa, 1986).

\subsubsection{Procedure Justice}

Procedure justice relates to the justice-determined allocation of resources to the employees (Greenberg, 1990). The managers and the employees participate to make the procedures to allocate the resources to the employees. The procedures ensure that this perceive allocation is fair, unbroken and reliable to all employees. Employees are heard, respected, and involved in decision-making as well as employees are shared with given fair information about enterprise policies to help them complete duties effectively. Shore and Shore (1995) said that the routine instances of justice in decisions regarding the allocation of resources would strongly influence perceived organizational support.

\subsubsection{Organizational Rewards}

According to the definition by Malhotra, Budhwar, and Prowse (2007), organizational rewards includes all monetary 
or non-monetary benefits paid to the employees based on their contributions to the organization. Employees conceived that the organization's wages, recognition, and promotion opportunities would affect employee behaviors. Shore and Shore (1995) said that human resource practice showed that rewarding the employee for his work performance should have a positive impact on the perceived organizational support. A range of rewards and working conditions have been studied in relation with perceived organizational support.

\subsection{Hypotheses Development}

\subsubsection{Organizational Rewards and Perceived Organizational Support}

According to the study on the organizational support, organizational rewards imparted a positive value to the contributions of employees to the organization and were therefore likely to make a positive contribution to the perceived organizational support (Eisenberger, Cummings, Armeli, \& Lynch, 1997). Eisenberger, Rhoades, And Cameron (1999) found that recognition, salary, and promotion positively affected the perceived organizational support. Rhoades. Eisenberger and Armeli (2001) concluded that the basic premise of the perceived organizational support included procedure justice, supervisor support, and organizational rewards. From these foundations, the authors developed the hypothesis:

H1: Organizational rewards positively impacts on perceived organizational support.

\subsubsection{Procedure Justice and Perceived Organizational Support}

DeConinck (2010) proved that procedure justice was a precursor to the perceived organizational support. The study's analysis was consistent with other researchers (Shore \& Shore, 1995; Rhoades, Eisenberger, \& Armeli, 2001). Moorman, Blakelydoes, and Niehoff (1998) concluded that perceived organizational support was an intermediate relationship between procedure justice and citizen behavior. Procedure justice implied the respect by an organization of the rights of its employees that had positive contributions to perceived organizational support because it could be realized as a facet of behavior and is revealing of the degree of perceived organizational support. Therefore, the authors proposed the following hypothesis:

H2: Procedure justice positively impacts on perceived organizational support.

\subsubsection{Perceived Supervisor Support and Perceived Organizational Support}

Hutchison (1997) found a positive correlation between perceived supervisor support and perceived organizational support. Onn and Lung (2014) found the correlation and link between supervisor support, organizational justice, and perceived organizational support. This study had the empirical intention to demonstrate the relationships and link between supervisor support and organizational justice and organizational support in private universities in Malaysia. Rhoades, Eisenberger and Armeli (2001) found that perceived supervisor support positively impacts on perceived organizational support. When the supervisor is concerned about the employee's value, he helps employee to solve the problems and recognizes the employee's job performance; the employee certainly has good perception on the organizational support. Thus, the authors proposed the following hypothesis:

H3: Perceived supervisor support positively impacts on perceived organizational support.

\subsubsection{Perceived Organizational Support Impact on Affective Commitment}

According to the theory of organizational support, in return for a certain support, employees would make an effort to work in order to help their enterprises achieve the set objectives (Aselage \& Eisenberger, 2003). Perceived organizational support had a positive influence on job satisfaction and organizational commitment (Rhoades \& Eisenberger, 2002). Currie and Dollery (2006) pointed out that perceived organizational support was highly significant in increasing affective and moral commitments, but had no impact on continuance commitment. Therefore, the study of perceived organizational support needed to be continually examined to ensure the expected results for the organization, thereby ultimately leading to effective outcome (Krishnan \& Mary, 2012). Organizational commitment was one of the most important results of perceived organizational support. Therefore, the authors developed the following hypothesis:

H4: Perceived organizational support positively impacts on perceived organizational support.

Based on hypotheses of the relationship of organizational rewards, procedure justice, perceived supervisor support and perceived organizational support as well as the hypothesis of the impact of perceived organizational support on affective commitment in the logistic industry, the research model of this study is proposed as follows (see Figure 1): 


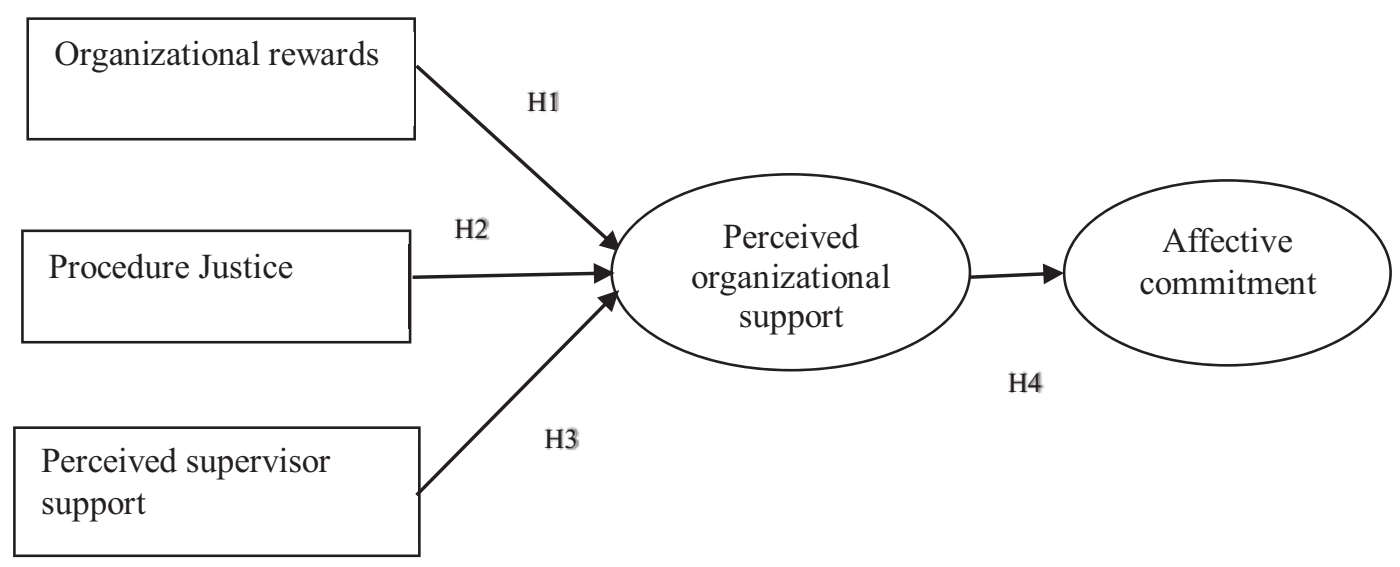

Figure 1: Proposed research model

\section{Research Methods}

\subsection{Research Sample}

According to Hair, Black, Babin, Anderson, and Tatham (1998), to make regression analysis achieve the best results, the sample size must satisfy the formula $\mathrm{n} \geq 5 \mathrm{~m}$ (where $\mathrm{m}$ is the number of the observed variables of independent variables). The study included 29 observed items of independent variables, so the sample size needed to be higher than 145 employees. The sample size of this study included 180 employees who were selected through a convenience sample at ten logistics companies.

\subsection{Research Scale}

The reward scale consisted of four observed variables (Eisenberger, Cummings, Armeli, \& Lynch, 1997). The procedure justice scale consisted of three observed variables (Farmer, Beehr, \& Love, 2003). The perceived supervisor support scale measured six observed variables (Shanock \& Eisenberger, 2006). The perceived organizational support scale was measured by 16 observed variables (Eisenberger, Huntington, Huchison, \& Sowa, 1986). The affective commitment scale was measured by six observed variables (Meyer \& Allen, 1991).

\section{Research Results}

\subsection{Descriptive Statistics}

Some 220 questionnaires were distributed and 198 questionnaires were collected. After eliminating unsatisfactory questionnaires, 180 valid questionnaires were retained, accounting for $81 \%$ of the original questionnaires. 180 employees were classified to participate by gender, age, educational level, working time as shown in Table 1 .
Table 1: Result of analysis of the research sample

\begin{tabular}{|l|c|c|}
\hline Sample division & Quantity & Percentage (\%) \\
\hline Gender & & \\
\hline Male & 100 & 55.6 \\
\hline Female & 80 & 44.4 \\
\hline Based on level & & \\
\hline Intermediate & 58 & 32.2 \\
\hline College & 68 & 37.8 \\
\hline University & 53 & 29.4 \\
\hline Postgraduate & 1 & 0.6 \\
\hline Seniority & & \\
\hline Less than 5 years & 153 & 85.0 \\
\hline $\begin{array}{l}\text { From 5 years to less } \\
\text { than 10 years }\end{array}$ & 20 & 11.1 \\
\hline Over 10 years & 7 & 3.9 \\
\hline
\end{tabular}

The results showed that the research sample is generally representative of employees in the logistics industry on gender, educational level, age, and working time.

\subsection{Results of Reliability of the Scales}

All scales had Cronbach's Alpha coefficient $>0.6$, the scales also had a correlative coefficient of total observed variables $>0.3$. This result showed that the scales were reliable and observed variables of the scales were retained for further analyses (see Table 2).

\subsection{Results of EFA Analysis}

As per the analysis of EFA, the scale of independent variables, the $\mathrm{KMO}$ coefficient $=0.946>0.5$ indicated that 
Table 2: Results of reliability of the scales

\begin{tabular}{|l|c|c|c|}
\hline \multicolumn{1}{|c|}{ Scale } & Number of Items & Cronbach's Alpha & Smallest item-total correlation \\
\hline Organizational rewards & 4 & 0.902 & 0.737 \\
\hline Procedure Justice & 3 & 0.727 & 0.468 \\
\hline Perceived supervisor support & 6 & 0.914 & 0.611 \\
\hline Perceived organizational support & 16 & 0.967 & 0.604 \\
\hline Affective commitment & 6 & 0.939 & 0.736 \\
\hline
\end{tabular}

Table 3: Results of EFA analysis of independent variables

\begin{tabular}{|c|c|c|c|}
\hline Variable & Item & Code & Factor loading \\
\hline \multirow{4}{*}{$\begin{array}{l}\text { Organizational } \\
\text { rewards }\end{array}$} & The company will recognize if I do my job well & OR2 & .824 \\
\hline & The company will reward promptly if I do my job well & OR3 & .772 \\
\hline & I have the opportunity for promotion in the company & OR1 & .762 \\
\hline & I have the opportunity to increase income in the company & OR4 & .719 \\
\hline \multirow{3}{*}{$\begin{array}{l}\text { Procedure } \\
\text { Justice }\end{array}$} & $\begin{array}{l}\text { The company usually holds meetings that allow me and my } \\
\text { colleagues to participate in discussion }\end{array}$ & PJ3 & .520 \\
\hline & $\begin{array}{l}\text { Business decisions at the company often collect opinions of } \\
\text { employees }\end{array}$ & PJ2 & .894 \\
\hline & I am often informed important things related to my work & PJ1 & .649 \\
\hline \multirow{6}{*}{$\begin{array}{l}\text { Perceived } \\
\text { supervisor } \\
\text { support }\end{array}$} & The supervisor is very interested in my goals and values. & PSS2 & .560 \\
\hline & The supervisor really pays attention on my welfare. & PSS1 & .786 \\
\hline & My supervisor will support me when I need his support. & PSS5 & .672 \\
\hline & The supervisor is proud of my accomplishments at work. & PSS6 & .646 \\
\hline & The supervisor is interested in my comments. & PSS3 & .639 \\
\hline & The supervisor is very concerned about me. & PSS4 & .605 \\
\hline
\end{tabular}

the EFA analysis was appropriate. The sig value in the Bartlett test $=0.000 \leq 0.05$, indicating that the observed variables were correlated with each other in total. Cumulative variance value was $73.572 \%>50 \%$, showing that the factors given from the analysis could explain $73.572 \%$ of the variation of the original survey data. Eigenvalue coefficient value $=$ $1.669>1$ was eligible to extract into three factors. The factor loading of observed variables in each factor was greater than 0.5 , indicating the convergence of the scales (see Table 3 ).

Under the analysis of scale of perceived organizational support, the KMO coefficient $=0.963>0.5$ indicated that the EFA analysis was suitable. The sig value $=0.000 \leq 0.05$ in the Bartlett inspection demonstrated that the observed variables were correlated with each other in total. Cumulative variance value was $67.124 \%>50 \%$, showing that the factors given from the analysis could explain $67,124 \%$ of the variation of the original survey data. The eigenvalue coefficient value was $10.74>1$ extracted into one factor. As a result of Table 4, all 16 observed variables had factor loading greater than 0.5 , so the scale had convergence (see Table 4).

Through the analysis of affective commitment scale, KMO coefficient $=0.9908>0.5$ indicated that the EFA analysis was suitable. The sig value $=0.000 \leq 0.05$ in the Bartlett inspection presented that the observed variables were correlated with each other in total. Cumulative variance value was $76.904 \%>50 \%$, showing that the factors given from the analysis could explain $76.904 \%$ of the variation of the original survey data. Eigenvalue coefficient value was 4.614> 1 extracted into one factor. As a result of Table 5, all 16 observed variables had factor loading greater than 0.5 , so the scale had convergence (see Table 5).

\subsection{Hypotheses Test}

The correlation matrix table showed that the independent variables of organizational rewards, procedure justice, 
Table 4: Results of perceived organizational support scale EFA analysis

\begin{tabular}{|l|l|c|c|}
\hline \multicolumn{1}{|c|}{ Variable } & \multicolumn{1}{|c|}{ Item } & Code & Factor loading \\
\hline \multirow{5}{*}{} & The enterprise evaluates my contributions through welfare. & POS12 & .862 \\
\cline { 2 - 4 } & $\begin{array}{l}\text { The enterprise will not replace my position even if they recruit } \\
\text { someone at a lower salary. }\end{array}$ & POS8 & .859 \\
\cline { 2 - 4 } & Any attempt by me is appreciated by the enterprise. & POS1 & .856 \\
\cline { 2 - 4 } & The enterprise always cares about my needs and desires. & POS14 & .852 \\
\cline { 2 - 4 } & The enterprise always reviews my complaints. & POS1 & .839 \\
\cline { 2 - 4 } $\begin{array}{l}\text { Perceived } \\
\text { organizational } \\
\text { support }\end{array}$ & $\begin{array}{l}\text { The enterprise cares about my rights and best benefits when they } \\
\text { make decisions that related to me. }\end{array}$ & POS10 & .837 \\
\cline { 2 - 4 } & I always get help from the enterprise whenever I have problems. & POS3 & .834 \\
\cline { 2 - 4 } & The enterprise really pays attention on my welfare. & POS13 & .834 \\
\cline { 2 - 4 } & $\begin{array}{l}\text { The enterprise always meets my reasonable requests for improvement } \\
\text { of working conditions. }\end{array}$ & POS6 & .833 \\
\cline { 2 - 4 } & The enterprise is ready to support when I need the support. & POS16 & .825 \\
\cline { 2 - 4 } & The enterprise pays attention on my overall satisfaction at work. & POS9 & .815 \\
\cline { 2 - 4 } & The enterprise will not "take advantage" of me in any case. & POS2 & .801 \\
\cline { 2 - 4 } & The enterprise is very interested in me. & POS7 & .800 \\
\cline { 2 - 4 } & The enterprise is interested in my comments. & POS5 & .798 \\
\cline { 2 - 4 } & The enterprise prides itself on my job performance. & POS15 & .797 \\
\cline { 2 - 4 } & The enterprise always finds the way to make my job more meaningful. & POS4 & .641 \\
\hline
\end{tabular}

Table 5: Result of affective commitment scale EFA analysis

\begin{tabular}{|l|l|c|c|}
\hline Variable & \multicolumn{1}{|c|}{ Item } & Code & Factor loading \\
\hline \multirow{5}{*}{$\begin{array}{l}\text { Affective } \\
\text { commitment }\end{array}$} & I'm glad to have chosen the enterprise to work for. & AC6 & .913 \\
\cline { 2 - 4 } & I feel that the enterprise's difficult problems are also my problems. & AC3 & .903 \\
\cline { 2 - 4 } & I feel I belong to the enterprise. & AC5 & .897 \\
\cline { 2 - 4 } & I see the enterprise as my second home. & AC1 & .882 \\
\cline { 2 - 4 } & I have the feeling this enterprise is a family and I am a member. & AC4 & .850 \\
\cline { 2 - 4 } & \multicolumn{2}{|c|}{ The enterprise has a particular importance to me. } & AC2 \\
\hline
\end{tabular}

and perceived supervisor support were correlated with perceived organizational support at $1 \%$ significance level. The perceived organizational support variable was correlated quite high with affective commitment variable at $1 \%$ significance level, so it is eligible for being put into regression analysis. Besides, the linear correlation between the independent variables is inconclusive with the multicollinear phenomenon (see Table 6).

Regression analysis results in model 1 showed that the regression model had an adjusted R2 coefficient of 0.862 . The adjusted R2 coefficient showed that three independent variables of organizational rewards, procedure justice, and perceived supervisor support could explain 86.2\% of the variation of the dependent variable as perceived organizational support. ANOVA analysis of regression model with Sig. $=0.000<0.05$ showed the overall suitability of the regression model. Regression analysis results in model 2 showed that the regression model had an adjusted R2 coefficient of 0.849 . The adjusted $\mathrm{R} 2$ coefficient showed that the perceived organizational support variable could explain $84.9 \%$ of the variation of affective commitment variable (see Table 7). 
Table 6: Matrix table of correlation coefficients among variables

\begin{tabular}{|l|c|c|c|c|c|c|}
\hline \multicolumn{1}{|c|}{ Variable } & Code & OR & PJ & PSS & POS & AC \\
\hline Organizational rewards & OR & 1 & $.598^{* *}$ & $.829^{* *}$ & $.850^{* *}$ & \\
\hline Procedure justice & PJ & & 1 & $.606^{* *}$ & $.652^{* *}$ & \\
\hline Perceived supervisor support & PSS & & & 1 & $.908^{* *}$ & \\
\hline Perceived organization support & POS & & & & 1 & $.922^{* *}$ \\
\hline Affective commitment & AC & & & & 1 \\
\hline Note: ${ }^{* *}=p<0.01$
\end{tabular}

Table 7: Matrix table of correlation coefficient among variables

\begin{tabular}{|c|c|c|c|c|c|}
\hline \multirow{2}{*}{ Hypothesis } & \multirow{2}{*}{ Variable } & Model 1 & Model 2 & \multirow{2}{*}{ Sig } & \multirow{2}{*}{ Result } \\
\hline & & POS & AC & & \\
\hline $\mathrm{H}_{1}$ & OR & 0.687 & & .000 & Accepted \\
\hline $\mathrm{H}_{2}$ & PJ & 0.578 & & .000 & Accepted \\
\hline $\mathrm{H}_{3}$ & PSS & 0.242 & & .000 & Accepted \\
\hline $\mathrm{H}_{4}$ & POS & & 0.922 & .000 & Accepted \\
\hline \multicolumn{2}{|c|}{ Adjusted R Square } & 0.862 & 0.849 & & \\
\hline \multicolumn{6}{|c|}{ Anova Sig. $=.000^{\mathrm{b}}$ Durbin-Watson $=1.995$} \\
\hline \multicolumn{6}{|c|}{$\begin{array}{l}\text { Note: OR = Organizational rewards; PJ= Procedure Justice; PSS = Perceived supervisor support; POS = POS; } \\
\text { AC = Affective commitment. }\end{array}$} \\
\hline
\end{tabular}

Table 7 showed that Durbin-Watson $=1.99$ could conclude that residual independence was guaranteed. The residual Histogram had a standard distribution with an average value of almost 0 and its standard deviation was 0.992 close to 1 . That meant the residual data had a standard distribution. Variance inflation factors (VIF) were all $<10$, so it could be concluded that the model didn't generate a multi-collinear phenomenon. Hypotheses H1, H2, H3, and H4 under the inspection had all Sig. value $<0.0001$ so the hypotheses were all accepted.

\section{Conclusion and Recommendations}

\subsection{Conclusion}

The regression analysis results found the organizational rewards, procedure justice, and perceived supervisor support positively impact on the perceived organizational support, and the perceived organizational support influences on affective commitment to the enterprise in the logistics industry. In particular, the organizational rewards, procedure justice, perceived supervisor support all positively impacted the perceived organizational support at Sig. value $<0.0001$. Organizational rewards with standardized $\beta=0.687$ had the strongest impact on the perceived organizational support. The organizational procedure justice with $\beta$ standardized $=0.578$ and perceived the support of supervisors with standardized $\beta$ $=0.242$ had a lower impact on the perceived organizational support. The perceived organizational support positively and strongly influenced affective commitment of the employees with standardized $\beta=0.992$.

This result had significance for the theory that in addition to the factors of salary, leadership, colleague relationship, training and promotion affecting affective commitment, the affective commitment also depended on a series of factors that related to each other from organizational rewards, procedure justice, perceived supervisor support, perceived organizational support and from organizational support to affective commitment. This study also had significance for managers, helped them understand concepts in this study, pay attention to implementing and measuring the performance of factors of organizational rewards, procedure justice, perceived supervisor support, perceived organizational support and affective commitment in human resource management.

\subsection{Recommendations}

\subsubsection{Organizational Rewards}

The organizational rewards are rated by the staff at forwarding companies at the mean level $=3.37$. Therefore, 
managers should need to pay attention to rewards and promotions for employees to improve the perceived organizational support. Transparent pay and bonus policy, accurate and timely rewards could reinforce the perceived organizational support that result in the efforts of the employees in order to attain organizational goals and increase the competitiveness of the enterprise. Each company should set up a specific reward policy based on the laws, fairness to the companies in the same industry and the financial capacity of the company. Rewards must be tied to goal accomplishment, justice, and timeliness. Rewards should include monetary rewards and merit rewards, recognition, and also promotion in career for qualified employees.

\subsubsection{Procedure Justice}

Organizational procedure justice was rated by the staff of the forwarding companies at the mean level $=3.13$. Managers should regularly organize monthly meetings so that employees could participate in order to make decision. Therefore, the problems in work are also found out so that everyone discusses to find the solutions to solve these problems. Managers could also arrange individuals with different expertise to work in a team to support and learn each other in their work. Fair and impartial treatments of employees at work are important to improve the loyalty and working morale of employees at the enterprise. Listening skills and giving opportunities for employees to contribute ideas are also the factor that leaders needed to take care to help employees express their personal views at work. Besides, managers should fairly share the organizational information includes target, plan, compensation system, human resource development system, appraisal system for all employees to support them to complete their duties.

\subsubsection{Perceived Supervisor Support}

Perceived supervisor support was rated by the staff at forwarding companies at the mean level $=3.47$. The supervisors should pay attention to the goals and employee values and satisfy their values in management practice. The supervisors need to evaluate and recognize timely the work achievements of the employees. The supervisors should oversee the works of the employees and compliment them for their job performance. Compliments must come from the sincerity of the supervisor, and an effective compliment is offered promptly after the works are completed by the employees. The supervisor should provide constructive feedback to avoid making the employees feel unsatisfied. If the employees show their reduced working capacity or make mistakes in handling the works, the supervisor needs time to review and find out the cause of the problem. In this situation, the supervisors need to create constructive opened communication and provide advisory solutions to help the employees at any time they need supervisor's support.

\subsubsection{Perceived Organizational Support}

Perceived organizational support was rated by the staff of the forwarding companies at the mean level $=3.25$. The managers need to take care of their employees to create a good management practice as well as payment for the benefits to their employees. The enterprises care about employee benefits such as workload, working time, vacation, holiday, training and other benefits received in compliance with the labor law and enterprise's compensation policy. In addition, the managers need to support the employees when they suffer from any problem, and proactively provide support before the employees move first. In special cases, the company can stand out to mobilize the employees to help and share difficulties with colleagues both mentally and physically. The company needs to keep the communication channel with the employees open so that they regularly have a chance to raise the voice at work. The company needs to clearly understand the needs and desires of the development of employees and have the career path for them. The company also facilitates the job rotation for employees to other suitable positions suiting their expertise and aspirations. As a result, they perceive the work is interesting and have the opportunity to develop.

\subsection{Limitations of the Study}

Although this study made theoretical and practical contributions, there were still limitations that need to be considered to determine the following research direction. The study chose samples by the convenience sampling method and the sample size of the study was small. The study also didn't study differences in affective commitment by demographics such as gender, age, educational level, and working time. This study also didn't identify the group of enterprises that applied well organizational rewards, procedure justice, perceived supervisor support, and affective commitment to become a model for learning. The regression data processing method failed to verify the intermediary role of perceived organizational support between organizational rewards, procedure justice, and perceived supervisor support and affective commitment. In addition, this study failed to further verify new variables that may affect the perceived organizational support such as training and development system, and performance evaluation system. These limitations should be addressed in further research directions. 


\section{References}

Allen, N. J., \& Meyer, J. P. (1990). The measurement and antecedents of affective, continuance and normative commitment to the organization. Journal of Occupational Psychology, 63(1), 1-18.

Aselage, J., \& Eisenberger, R. (2003). Perceived organizational support and psychological contracts: A theoretical integration. Journal of Organizational Behavior: The International Journal of Industrial, Occupational and Organizational Psychology and Behavior, 24(5), 491-509.

Currie, P., \& Dollery, B. (2006). Organizational commitment and perceived organizational support in the NSW police. Policing: An International Journal of Police Strategies \& Management, 29(4), 741-756.

DeConinck, J. B. (2010). The effect of organizational justice, perceived organizational support, and perceived supervisor support on marketing employees' level of trust. Journal of Business Research, 63(12), 1349-1355.

Doan, T. T. T., Nguyen, L. C. T., \& Nguyen, T. D. N. (2020). Emotional Intelligence and Project Success: The Roles of Transformational Leadership and Organizational Commitment. Journal of Asian Finance, Economics and Business, 7(3), 223233. https://doi.org/10.13106/jafeb.2020.vol7.no3.223

Eisenberger, R., Cummings, J., Armeli, S., \& Lynch, P. (1997). Perceived organizational support, discretionary treatment, and job satisfaction. Journal of Applied Psychology, 82(5), 812820 .

Eisenberger, R., Huntington, R., Hutchison, S., \& Sowa, D. (1986). Perceived organizational support. Journal of Applied Psychology, 71(3), 500-507.

Eisenberger, R., Rhoades, L., \& Cameron, J. (1999). Does pay for performance increase or decrease perceived self-determination and intrinsic motivation?. Journal of Personality and Social Psychology, 77(5), 1026-1040.

Eisenberger, R., Stinglhamber, F., Vandenberghe, C., Sucharski, I. L., \& Rhoades, L. (2002). Perceived supervisor support: contributions to perceived organizational support and employee retention. Journal of Applied Psychology, 87(3), 565-573.

Farmer, S. J., Beehr, T. A., \& Love, K. G. (2003). Becoming an undercover police officer: A note on fairness perceptions, behavior, and attitudes. Journal of Organizational Behavior: The International Journal of Industrial, Occupational and Organizational Psychology and Behavior, 24(4), 373-387.

George, J. M., Reed, T. F., Ballard, K. A., Colin, J., \& Fielding, J. (1993). Contact with AIDS patients as a source of work-related distress: Effects of organizational and social support. Academy of Management Journal, 36(1), 157-171.

Greenberg, J. (1990). Organizational justice: Yesterday, today, and tomorrow. Journal of Management, 16(2), 399-432.

Hair, J. F., Black, W. C., Babin, B. J., Anderson, R. E., \& Tatham, R. L. (1998). Multivariate data analysis. Upper Saddle River, NJ: Prentice hall.
Hutchison, S. (1997). Perceived organizational support: Further evidence of construct validity. Educational and Psychological Measurement, 57(6), 1025-1034.

Jain, A. K., \& Sinha, A. K. (2005). General Health in Organizations: Relative Relevance of Emotional Intelligence, Trust, and Organizational Support. International Journal of Stress Management, 12(3), 257-273.

Kottke, J. L., \& Sharafinski, C. E. (1988). Measuring perceived supervisory and organizational support. Educational and Psychological Measurement, 48(4), 1075-1079.

Krishnan, J., \& Mary, V. S. (2012). Perceived organisational supportan overview on its antecedents and consequences. International Journal of Multidisciplinary Research, 2(4), 2-3.

Malhotra, N., Budhwar, P., \& Prowse, P. (2007). Linking rewards to commitment: an empirical investigation of four UK call centres. The International Journal of Human Resource Management, 18(12), 2095-2128.

Mathieu, J. E., \& Zajac, D. M. (1990). A review and meta-analysis of the antecedents, correlates, and consequences of organizational commitment. Psychological Bulletin, 108(2), 171-194.

Meyer, J. P., \& Allen, N. J. (1991). A three-component conceptualization of organizational commitment. Human Resource Management Review, 1(1), 61-89.

Moorman, R. H., Blakely, G. L., \& Niehoff, B. P. (1998). Does perceived organizational support mediate the relationship between procedural justice and organizational citizenship behavior?. Academy of Management Journal, 41(3), 351-357.

Nguyen, M. H., \& Ngo, T. T. (2020). Psychological capital, organizational commitment and job Performance: A case in Vietnam. Journal of Asian Finance, Economics and Business, 7(5), 269-278. https://doi.org/10.13106/jafeb.2020.vol7. no5.269

Nguyen, T. H., \& Tu, V. B. (2020). Social Responsibility, Organizational Commitment, and Organizational Performance: Food Processing Enterprises in the Mekong River Delta. Journal of Asian Finance, Economics and Business, 7(2), 309316. https://doi.org/10.13106/jafeb.2020.vo17.no2.309

Onn, C. Y., \& Lung, C. K. (2014). Supervisory Support, Organizational Justice and Perceived Organizational Support: A Review and Research Agenda. Information Management and Business Review, 6(5), 255-260.

O'Reilly, C. A., \& Chatman, J. (1986). Organizational commitment and psychological attachment: The effects of compliance, identification, and internalization on prosocial behavior. Journal of Applied Psychology, 71(3), 492-499. https://doi.org/10.1037/0021-9010.71.3.492

Rhoades, L., \& Eisenberger, R. (2002). Perceived organizational support: a review of the literature. Journal of Applied Psychology, 87(4), 698-714.

Rhoades, L., Eisenberger, R., \& Armeli, S. (2001). Affective commitment to the organization: The contribution of perceived organizational support. Journal of Applied Psychology, 86(5), 825-836. 
Shanock, L. R., \& Eisenberger, R. (2006). When supervisors feel supported: Relationships with subordinates' perceived supervisor support, perceived organizational support, and performance. Journal of Applied Psychology, 91(3), 689-695.

Shore, L. M., \& Shore, T. H. (1995). Perceived organizational support and organizational justice. Organizational Politics,
Justice, and Support: Managing the Social Climate of the Workplace, 149-164.

Singh, R. K., Garg, S. K., \& Deshmukh, S. G. (2010). The competitiveness of SMEs in a globalized economy. Management Research Review, 33(1), 54-65. 